\title{
MODEL THINK PAIR SHARE DIDUKUNG RESITASI UNTUK MENINGKATKAN AKTIVITAS BELAJAR
}

\section{THE MODEL OF THINK PAIR SHARE AND SUPPORTED BY RESISTANCE TO INCREASE LEARNING ACTIVITIES}

\author{
Ali Usman \\ Universitas Muhammadiyah Jember \\ Email: aliu86541@gmail.com \\ diterima: 20 Desember 2018; dipublikasi : 30 Maret 2019 \\ DOI: http://dx.doi.org/10.32528/bioma.v4i1.2651
}

\begin{abstract}
ABSTRAK
Tujuan penelitian mendeskripsikan aktivitas belajar siswa dengan penerapan model pembelajaran TPS (Think Pair Share) didukung Resitasi. Jenis penelitian merupakan Penelitian Tindakan Kelas (PTK). Desain penelitian model siklus Hopkins yang terdiri dari empat fase yakni perencanaan (planning), tindakan (action), pengamatan atau observasi (observation), dan refleksi (reflection). Siklus penelitian akan terus berlanjut sampai mencapai tujuan penelitian. Perangkat pembelajaran yang digunakan berupa Silabus, Rancangan Pelaksanaan Pembelajaran (RPP) dan lembar observasi aktivitas belajar siswa. Hasil penelitian dilaporkan bahwa aktivitas belajar siswa kelas XI IPA 2 SMA Negeri 1 Kencong selama mengikuti pembelajaran biologi menggunakan model pembelajaran TPS (Think Phair Share) didukung Resitasi mengalami peningkatan dari pra siklus sebesar $69,7 \%$, siklus 1 sebesar $72,4 \%$ sampai siklus 2 sebesar $80,3 \%$.
\end{abstract}

Kata kunci: TPS, Resitasi, Aktivitas Belajar

\begin{abstract}
The purpose of the study is to describe student learning activities by applying the TPS (Think Pair Share) learning model supported by recitation. This type of research is Classroom Action Research (CAR). The Hopkins cycle model research design consists of four phases namely planning (planning), action (action), observation or observation (observation), and reflection (reflection). The research cycle will continue until it reaches the research objective.Learning devices used in the form of Syllabus, Learning Implementation Design (RPP) and observation sheets of student learning activities. The results of the study reported that the learning activities of students of class XI IPA 2 in Kencong 1 Public High School academic year while participating in biology learning using the Think Phair Share learning model supported by recitation experienced an increase from pre cycles do $69,7 \%$, cycle 1 to $72,4 \%$ and cycle 2 to $80,3 \%$.
\end{abstract}

Keywords: TPS, Recitation, Learning Activities 


\section{PENDAHULUAN}

Pembelajaran memegang peran sangat penting sekali dikarenakan berkembang atau tidaknya kemampuan atau potensi siswa ditentukan oleh pembelajaran. Hal senada diungkapkan oleh (Tjalla, 2014 ) yang menyatakan bahwa mutu pendidikan merupakan hal yang tidak dapat ditawar lagi dalam rangka meningkatkan sumber daya manusia. Maka untuk meningkatkan potensi siswa dalam proses pembelajaran pemerintah melakukan upaya pelatihan dan peningkatan kualitas guru. Pembelajaran merupakan proses belajar mengajar untuk memperoleh pengetahuan, keterampilan dan sikap, Dimyati dan Moedjiono (2002:157). Sudjana (1993:6) mendefinisikan pembelajaran sebagai interaksi antara guru dan siswa dalam rangka mencapai tujuan belajar mengajar. Jadi pembelajaran adalah proses interaksi antara guru dan siswa untuk membantu siswa dalam kegiatan pembelajaran sehingga salah satunya akan diperoleh sikap atau aktivitas belajar yang baik.

Kenyataan di lapangan saat ini proses pembelajaran bisa dikatakan tidak memberdayakan potensi siswa. Hal ini terlihat jelas dari hasil beberapa penelitian yang menyatakan bahwa proses pembelajaran di kelas bersifat konvensional (Bachtir, 2018 dan Ishak, 2018). Hasil penelitian tersebut sesuai dengan hasil observasi kelas XI IPA 2 di SMAN 1 Kencong Kabupaten Jember, diketahui saat proses pembelajaran frekuensi siswa dalam melakukan diskusi kelompok, presentasi, bertanya, menjawab pertanyaan, dan memperhatikan penjelasan guru frekuensinya masih sangat rendah sekali.

Belajar itu merupakan pemberdayaan potensi-potensi yang ada pada diri siswa dan hasil dari belajar akan berkembangnya pengetahuan, keterampilan dan sikap pada diri siswa. Dalam proses pembelajaran di kelas, siswa dikatakan belajar jika siswa mampu terlibat aktif baik secara rohani, fisik maupun mental dalam mengikuti proses pembelajaran tersebut, sehingga hasil dari pembelajaran maka potensi yang ada pada diri siswa mampu berkembang dengan baik. Peningkatan potensi siswa dalam belajar sangat perlu sekali dilakukan salah satunya yakni peningkatan aktivitas belajar. Aktivitas belajar adalah serangkaian kegiatan fisik atau jasmani maupun mental atau rohani yang saling berkaitan sehingga tercipta belajar yang optimal. Maulana (2016) menyatakan model pembelajaran TPS (Think Pair Share) mampu meningkatkan aktivitas belajar dengan cara siswa mendengarkan paparan dari siswa lain pada tahap 
share, hal tersebut akan membantu siswa mempelajari konsep serta ide baru yang disampaikan oleh siswa yang lain. Resitasi merupakan metode dimana siswa diberi tugas di luar jam pelajaran. Berdasarkan penelitian Wulandari (2013) menyatakan bahwa adanya perubahan aktivitas belajar siswa setelah penerapan metode Resitasi, siswa memiliki kedisiplinan yang tinggi, dan tanggung jawab yang lebih besar.

\section{METODE}

Jenis penelitian merupakan Penelitian Tindakan Kelas (PTK). Waktu penelitian semeter genap di kelas XI IPA 2 SMA Negeri 1 Kencong Kabupaten Jember. Jumlah siswa pada kelas tersebut sebanyak 38 siswa. Dengan target memperbaiki aktivitas belajar siswa yang masih rendah. Tindakan pendahuluan sebelum penelitian di antaranya yakni Observasi proses proses pembelajaran, wawancara dengan guru mata pelajaran dan diskusi tentang tindakan yang perlu diambil. Desain penelitian model siklus Hopkins yang terdiri dari empat fase yakni perencanaan (planning), tindakan (action), pengamatan atau observasi (observation), dan refleksi (reflection). Keempat fase saling berhubungan dalam bentuk siklus yang berulang. Siklus penelitian akan terus berlanjut sampai mencapai tujuan penelitian, siklus berikutnya merupakan siklus perbaikan atau siklus pemantapan dari hasil refleksi pada siklus sebelumnya.

Instrumen yang digunakan yakni perangkat pembelajaran berupa Silabus, Rancangan Pelaksanaan Pembelajaran (RPP), Lembar observasi aktivitas belajar. Lembar observasi aktivitas belajar dirujuk dari Trianto, 2010, dan dikembangkan oleh peneliti sesuai dengan model pembelajaran yang digunakan. Teknik pengumpulan data berupa wawancara dan observasi. Analisis data yakni analisis deskriptif. Lembar observasi aktivitas belajar terdiri dari delapan poin di antaranya yakni:

1. Ketepatan waktu dalam mengumpulkan tugas

2. Mengerjakan LKS secara mandiri

3. Melakukan diskusi dengan kelompok

4. Presentasi hasil diskusi

5. Kemampuan bertanya

6. Kemampuan menjawab pertanyaan

7. Memperhatikan penjelasan guru 
8. Menarik kesimpulan

\section{HASIL DAN PEMBAHASAN}

Hasil penelitian disajikan dalam bentuk data yang dibuat gambar. Terdapat delapan poin aktivitas belajar siswa di antaranya yakni; 1) Ketepatan waktu dalam mengumpulkan tugas, 2) Mengerjakan LKS secara mandiri, 3) Melakukan diskusi dengan kelompok, 4) Presentasi hasil diskusi, 5) Kemampuan bertanya, 6) Kemampuan menjawab pertanyaan, 7) Memperhatikan penjelasan guru, 8) Menarik kesimpulan.

Tabel 1. Data Aktivitas Belajar Siswa Pra Siklus

\begin{tabular}{lccccccccc}
\hline \multicolumn{1}{c}{ Observer } & $\mathbf{1}$ & $\mathbf{2}$ & $\mathbf{3}$ & $\mathbf{4}$ & $\mathbf{5}$ & $\mathbf{6}$ & $\mathbf{7}$ & $\mathbf{8}$ & Jumlah \\
\hline I & 27 & 24 & 25 & 10 & 0 & 3 & 30 & 3 & 122 \\
\hline II & 26 & 22 & 23 & 9 & 0 & 3 & 31 & 3 & 117 \\
\hline Rata-rata & 26,5 & 23 & 24 & 9,5 & 0 & 3 & 30,5 & 3 & 180,5 \\
\hline Persentase & 69,7 & 60,5 & 63,2 & 25,0 & 0,0 & 7,9 & 80,3 & 7,9 & 475,0 \\
$(\%)$ & & & & & & & & & \\
\hline Reliabilitas & 98,1 & 95,7 & 95,8 & 94,7 & 0,0 & 100,0 & 98,4 & 100,0 & 98,2 \\
\hline Reliabilitas & & & & & & & & & \\
Rata-Rata & & & & & & & & \\
$(\%)$ & & & & & 85,34 & & & \\
\hline
\end{tabular}

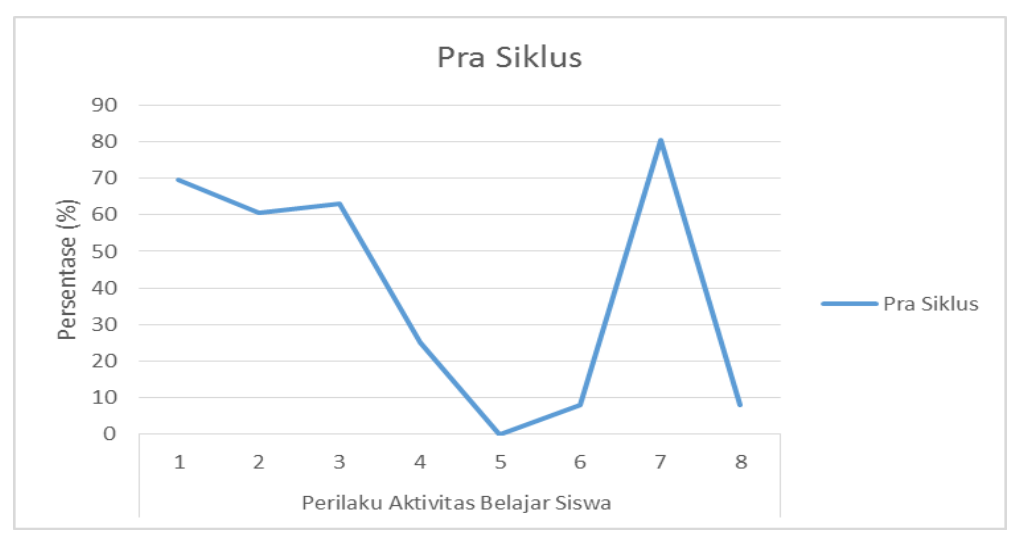

Gambar 1. Nilai Persentase Aktivitas Belajar Siswa Pra Siklus 
Berdasarkan Tabel 1 dan Gambar 1, diketahui poin aktivitas belajar siswa nomor satu sebesar $69,7 \%$, nomor dua sebesar $60,5 \%$, nomor tiga sebesar $63,2 \%$, nomor empat sebesar $25 \%$, nomor lima sebesar $0 \%$, nomor enam sebesar 7,9\%, nomor tujuh sebesar $80,3 \%$, nomor delapan sebesar $7,9 \%$.

Tabel 2. Data Aktivitas Belajar Siswa Siklus Satu

\begin{tabular}{llllllllll}
\hline \multicolumn{1}{c}{ Observer } & $\mathbf{1}$ & $\mathbf{2}$ & $\mathbf{3}$ & $\mathbf{4}$ & $\mathbf{5}$ & $\mathbf{6}$ & $\mathbf{7}$ & $\mathbf{8}$ & Jumlah \\
\hline I & 27 & 24 & 26 & 13 & 2 & 4 & 25 & 4 & 125 \\
\hline II & 28 & 23 & 24 & 10 & 2 & 3 & 28 & 6 & 124 \\
\hline Rata-rata & 27,5 & 23,5 & 25 & 11,5 & 2 & 3,5 & 26,5 & 5 & 187 \\
\hline Persentase & 72,4 & 61,8 & 65,8 & 30,3 & 5,3 & 9,2 & 69,7 & 13,2 & 492,1 \\
$(\%)$ & & & & & & & & & \\
\hline Reliabilitas & 98,2 & 97,9 & 96,0 & 87,0 & 100,0 & 85,7 & 94,3 & 80,0 & 99,3 \\
\hline $\begin{array}{l}\text { Reliabilitas } \\
\text { Rata-Rata }\end{array}$ & & & & & & & & \\
(\%) & & & & & & & & & \\
\hline
\end{tabular}

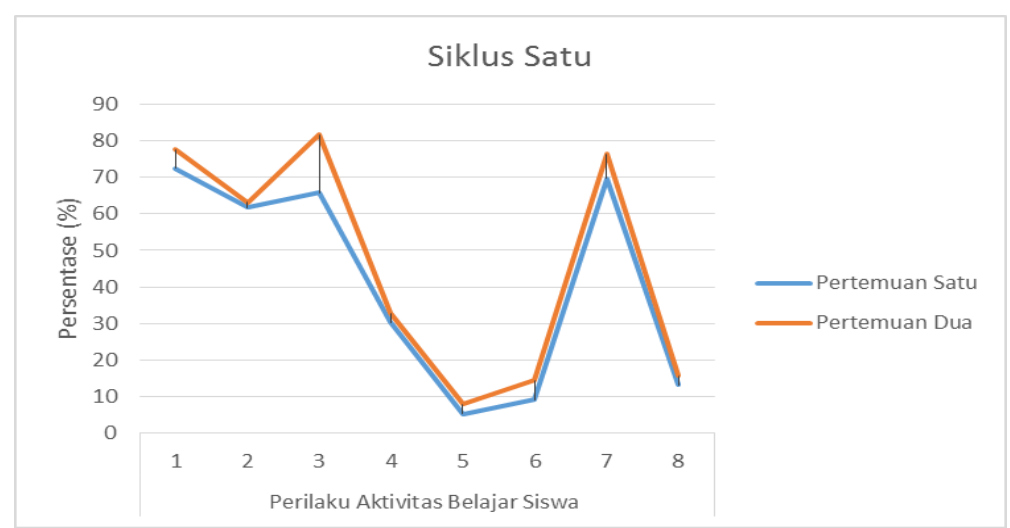

Gambar 2. Nilai Persentase Aktivitas Belajar Siswa Siklus Satu

Berdasarkan Tabel 2 dan Gambar 2 terdapat dua pertemuan yakni pertemuan satu dan pertemuan dua. Diketahui poin aktivitas belajar siswa nomor satu pada pertemuan satu sebesar $72,4 \%$ dan pada pertemuan dua sebesar $77,6 \%$, nomor dua pada pertemuan satu sebesar $61,8 \%$ dan pada pertemuan dua sebesar $63,2 \%$, nomor tiga pada pertemuan satu sebesar $65,8 \%$ dan pada pertemuan dua sebesar $81,6 \%$, nomor empat 
pada pertemuan satu sebesar 30,3\% dan pada pertemuan dua sebesar 32,9\%, nomor lima pada pertemuan satu sebesar $5,3 \%$ dan pada pertemuan dua sebesar $7,9 \%$, nomor enam pada pertemuan satu sebesar 9,2\% dan pada pertemuan dua sebesar 14,5\%, nomor tujuh pada pertemuan satu sebesar $69,7 \%$ dan pada pertemuan dua sebesar $76,3 \%$, nomor delapan pada pertemuan satu sebesar $13,2 \%$ dan pada pertemuan dua sebesar $15,8 \%$.

Tabel 3. Data Aktivitas Belajar Siswa Siklus Dua

\begin{tabular}{lccccccccc}
\hline \multicolumn{1}{c}{ Observer } & $\mathbf{1}$ & $\mathbf{2}$ & $\mathbf{3}$ & $\mathbf{4}$ & $\mathbf{5}$ & $\mathbf{6}$ & $\mathbf{7}$ & $\mathbf{8}$ & Jumlah \\
\hline I & 31 & 31 & 30 & 15 & 5 & 6 & 30 & 9 & 157 \\
\hline II & 30 & 34 & 32 & 14 & 5 & 7 & 29 & 6 & 157 \\
\hline Rata-rata & 30,5 & 32,5 & 31 & 14,5 & 5 & 6,5 & 29,5 & 7,5 & 235,5 \\
\hline Persentase & 80,3 & 85,5 & 81,6 & 38,2 & 13,2 & 17,1 & 77,6 & 19,7 & 619,7 \\
$(\%)$ & & & & & & & & & \\
\hline Reliabilitas & 98,4 & 95,4 & 96,8 & 96,6 & 100,0 & 92,3 & 98,3 & 80,0 & 98,3 \\
\hline $\begin{array}{l}\text { Reliabilitas } \\
\text { Rata-Rata }\end{array}$ & & & & & & & & \\
$(\%)$ & & & & & & & & & \\
\hline
\end{tabular}

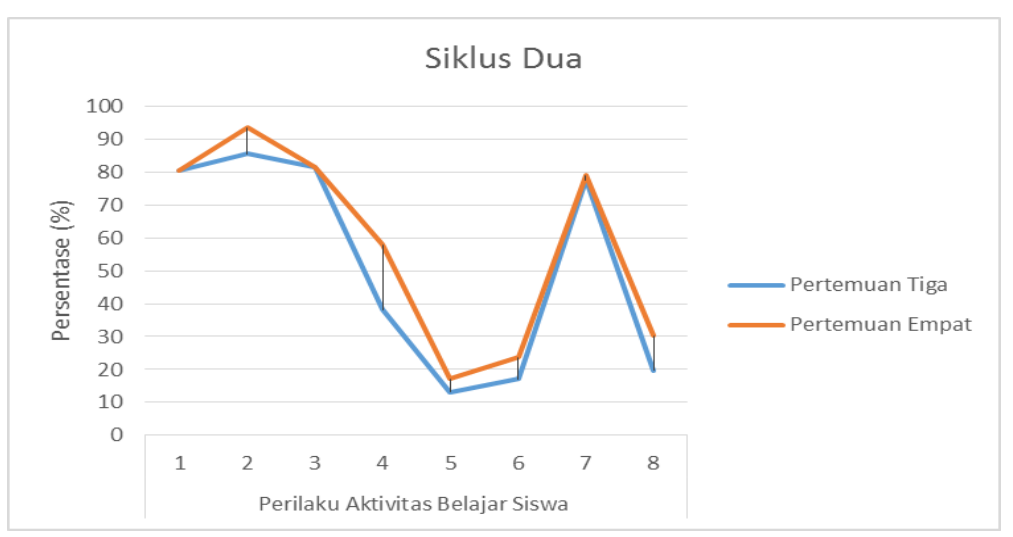

Gambar 3. Nilai Persentase Aktivitas Belajar Siswa Siklus Dua

Gambar Tabel 3 dan Gambar 3 juga terdapat dua pertemuan yakni pertemuan tiga dan empat. Berdasarkan poin aktivitas belajar siswa nomor satu pada pertemuan tiga sebesar $80,3 \%$ dan pada pertemuan empat sebesar $80,3 \%$, nomor dua pada pertemuan tiga sebesar $85,5 \%$ dan pada pertemuan empat sebesar 93,4\%, nomor tiga 
pada pertemuan tiga sebesar $81,6 \%$ dan pada pertemuan empat sebesar $81,6 \%$, nomor empat pada pertemuan tiga sebesar 38,2\% dan pada pertemuan empat sebesar 57,9\%, nomor lima pada pertemuan tiga sebesar $13,2 \%$ dan pada pertemuan empat sebesar $17,1 \%$, nomor enam pada pertemuan tiga sebesar $17,1 \%$ dan pada pertemuan empat sebesar $23,7 \%$, nomor tujuh pada pertemuan tiga sebesar $77,6 \%$ dan pada pertemuan empat sebesar 78,9\%, nomor delapan pada pertemuan tiga sebesar 19,7\% dan pada pertemuan empat sebesar 30,3\%.

Terjadi perubahan aktivitas belajar siswa pada setiap siklus penelitian. Perubahan tersebut yakni peningkatan aktivitas belajar siswa. Peningkatan aktivitas belajar siswa dapat terlihat jelas pada hasil penelitian yang disajikan dalam bentuk data yang dibuat dalam Gambar 1, 2 dan 3. Dari gambar tersebut memberikan pandangan yang jelas tentang bagaimana model pembelajaran mampu menaikkan aktivitas belajar siswa yang terdiri dari delapan poin. Sehingga dikatakan berdasarkan data dan hasil analisis bahwa penggunaan model pembelajaran dalam kelas mampu memberikan perubahan atau peningkatan pada potensi siswa salah satunya pada aktivitas belajar. Hal serupa disampaikan oleh Nambiar (2017) yang mengklaim bahwa menciptakan lingkungan belajar yang optimal itu sangat penting sekali yang membuat siswa lebih aktif dalam lingkungan sosial. Bahtiar (2016) dan Bialangi, et al. (2016) juga menyatakan bahwa sikap atau aktivikasi belajar siswa dapat disebabkan oleh model pembelajaran yang diterapkan di kelas. Jadi dapat disimpulkan bahwa dengan penerapan model pembelajaran akan menjadi wadah dalam meningkatkan aktivitas belajar siswa.

Hasil pada siklus pembelajaran aktivitas belajar siswa terjadi peningkatan dengan menggunakan model TPS (Think Pair Share) didukung metode Resitasi. Hasil penelitian ini sama dengan temuan, Haataja, et, all (2018); Neykki et, all (20017), Palumbo et la (2017) yang menyatakan bahwa pembelajaran kelompok itu sangat baik sekali dalam aktivitas belajar siswa. Peningkatan aktivitas belajar siswa paling banyak yakni ketepatan waktu dalam mengumpulkan resume, mengerjakan LKS secara mandiri, melakukan diskusi dengan kelompok dan presentasi hasil diskusi. Sehingga dapat dikatakan model pembelajaran mampu memberikan kesempatan kepada setiap siswa untuk menunjukkan partisipasi mereka. 
Tugas yang dikerjakan di luar jam pelajaran atau resitasi, mampu mengembangkan pola pikir siswa dalam mengungkapkan pemikiran siswa dalam menyelesaikan suatu permasalahan sehingga merangsang siswa aktivitas belajar baik individual ataupun kelompok. Metode Resitasi memberikan pengetahuan awal kepada siswa dari materi yang akan dipelajari di kelas, sehingga dalam proses pembelajaran siswa sudah mempunyai pengetahuan awal dan guru lebih mudah untuk membangun pengetahuan siswa. Model pembelajaran TPS didukung Resitasi membuat proses pembelajaran berjalan lebih fleksibel dan guru tidak perlu lagi melakukan ceramah terhadap materi pelajaran, guru tinggal membangun pengetahuan awal yang dimiliki oleh siswa. Hal senada juga dilaporkan oleh Suranakkharin (2017) yang melaporkan bahwa proses belajar yang fleksibel di mana siswa belajar secara mandiri di luar jam pelajaran untuk membentuk pengetahuan awalnya kemudian membawa pengetahuan awalnya tersebut ke dalam kelas akan membantu mendorong siswa berinteraksi dengan teman sebaya dan guru yang pada gilirannya akan membuat siswa menjadi lebih aktif belajar. Djamarah, (2006) juga menyatakan bahwa tugas yang diberikan kepada siswa mengembangkan pola pikir dalam mengungkapkan pendapat dan ide untuk menyelesaikan suatu permasalahan

\section{KESIMPULAN DAN SARAN}

Berdasarkan data, analisis data dan pembahasan hasil penelitian dapat diperoleh kesimpulan yakni aktivitas belajar siswa kelas XI IPA 2 SMA Negeri 1 Kencong selama mengikuti pembelajaran biologi menggunakan model pembelajaran kooperatif tipe TPS (Think Phair Share) didukung metode Resitasi mengalami peningkatan dari pra siklus sebesar 69,7\%, siklus 1 sebesar 72,4\% sampai siklus 2 sebesar 80,3\%.

Berdasarkan hasil penelitian dan pembahasan, maka saran yang diberikan sebagai berikut:

a. Diskusi dalam proses pembelajaran sangat perlu diselenggarakan dalam proses pembelajaran di kelas

b. Guru hendaknya melakukan inovasi dalam pembelajaran untuk meningkatkan potensi pada diri siswa salah satunya dengan menggunakan model pembelajaran. 
c. Sebelum pembelajaran di mulai hendaknya siswa sudah memiliki pemahaman awal tentang materi yang akan dipelajari di sekolah sehingga dalam proses pembelajaran siswa tinggal pemantapan materi saja dengan mengerjakan latihan atau persoalan yang diberikan oleh guru.

\section{DAFTAR PUSTAKA}

Bachtiar, S. (2018). Pengaruh Integrasi Problem Based Learning (PBL) dan Numbered Heads Together (NHT) pada Kemampuan Akademik Berbeda terhadap Motivasi, Sikap, Metakognisi, Keterampilan Berpikir Kritis, dan Hasil Belajar Kognitif Biologi Siswa SMAN di Kabupaten Jeneponto. Disertasi tidak diterbitkan. Malang:PPS UM

Bahtiar. (2016). Pembelajaran Kooperatif untuk Meningkatkan Sikap Sosial dan Pemahaman Konsep Siswa Sekolah Multietnis. Jurnal Edukasi Matematika dan Sains, 3 (1), 1-13.

Bialangi, S.M., Zubaidah, S., Amin, M., \& Gofur, A. (2016). Development of Students' Social Attitudes In Biology Classroom Through Jigsaw And Guided Inquiry. International Journal Of Academic Research And Development, 1 (10), 01-07)

Haataja, E., Malmberg, J., \& Järvelä, S. (2018). Monitoring in collaborative learning: Co-occurrence of observed behavior and physiological synchrony explored. Computers in Human Behavior, 87, 337-347. doi:10.1016/j.chb.2018.06.007 Internasional. Artikel. (Online), (http://www.pustaka.ut.ac.id), diakses tanggal 3 Pebruari 2016.

Ishak, F. (2018). Pengaruh Strategi Pembelajaran TPS (Think Pair Share) dan TTW (Think Talk Write) terhadap Kemampuan Metakognisi Berpikir Kritis dan Retensi Siswa MA di Malang Raya. Tesis tidak diterbitkan. Malang:PPS UM Maulana, I. (2016). Pengaruh Strategi Pembelajaran PBL dan TPS terhadap Keterampilan Metakognitif, Keteramplan Berpikir Kritis, dan Retensi pada Siswa 
dari Etnis yang Berbeda di Kota Metro. Tesis tidak diterbitkan. Malang:PPS $\mathrm{UM}$

Nambiar, R.M.K., Nor, N.Z., Ismail, K., Adam, S. (2017). New Learning Spaces Ana Transformations in Teacher Pedagogy and Student Learning Behavior in the Language Learning Classroom. 3L: The Southeast Asian Journal of English Language Studies - Vol 23(4): 29 - 40 http://doi.org/10.17576/3L-2017-2304-03

Palumbo, R. V., Marraccini, M. E., Weyandt, L. L., Wilder-Smith, O., McGee, H. A., Liu, S., \& Goodwin, M. S. (2017). Interpersonal autonomic physiology: A systematic review of the literature. Personality and Social Psychology Review, 21(2), 99-141. https://doi.org/10.1177/1088868316628405

Setiawati, H. (2017). Pengaruh Strategi Pembelajaran PQ4R dipadu TPS pada Kemampuan Akademik Berbeda Terhadap Keterampilan Metakognitif, Keterampilan Berpikir Kritis, Pemahaman Konsep, Retensi, dan Sikap Ilmiah Biologi Siswa SMA di Kota Parepare. Disertasi tidak diterbitkan. Malang:PPS $\mathrm{UM}$

Suranakkharin, T. (2017). Using the Flipped Model to Foster Thai Learners' Second Language Collocation Knowledge. 3L: The Southeast Asian Journal of English Language Studies - Vol 23(3): 1 - 20 http://doi.org/10.17576/3L-2017-2303-01

Tjalla, A. (2014). Potret Mutu Pendidikan Indonesia Ditinjau dari Hasil-Hasil Studi Wulandari, Y. (2013). Penerapan Metode Resitasi Kelompok Berbasis Karakter Untuk Meningkatkan Hasil Belajar Siswa Kelas XI TKR 1 Di SMK PGRI Sidoarjo. Jurnal. Surabaya 